\title{
Implementation project of object recognition system to the modular didactic system of manufacturing gearings
}

Bartłomiej WIETRAK, Tomasz CHACIŃSKI

DOI: 10.30464/jmee.2021.5.1.39

Cite this article as:

Wietrak B., Chaciński T. Implementation project of object recognition system to the modular didactic system of manufacturing gearings. Journal of Mechanical and Energy Engineering, Vol. 5(45), No. 1, 2021, pp. 39-44.

\section{VOLUME 5(45) | No. 1 | MARCH 2021}

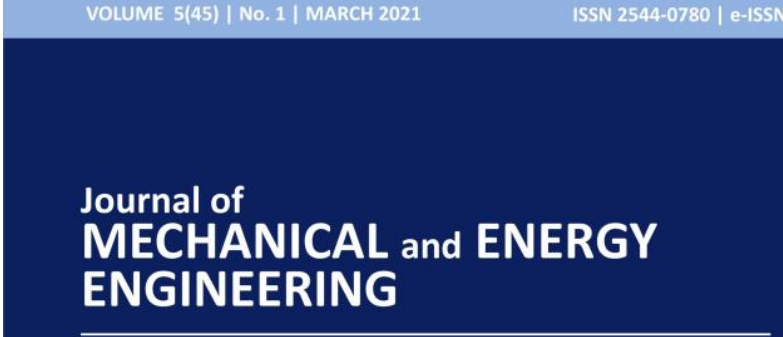

Editor-in-Chief

Waldemar Kuczyński

Editors

Krzysztof Nadolny

\section{Journal of Mechanical and Energy} Engineering

Website: jmee.tu.koszalin.pl

ISSN (Print): 2544-0780

ISSN (Online): 2544-1671

Volume: 5(45)

Number: 1

Year: 2021

Pages: 39-44

\section{Article Info:}

Received 15 January 2021

Accepted 31 January 2021

\section{Open Access}

This article is distributed under the terms of the Creative Commons Attribution 4.0 (CC BY 4.0) International License (http://creativecommons.org/licenses/by/4.0/), which permits unrestricted use, distribution, and reproduction in any medium, provided you give appropriate credit to the original author(s) and the source, provide a link to the Creative Commons license, and indicate if changes were made. 


\title{
IMPLEMENTATION PROJECT OF OBJECT RECOGNITION SYSTEM TO THE MODULAR DIDACTIC SYSTEM OF MANUFACTURING GEARINGS
}

\author{
Bartłomiej WIETRAK $^{1^{*}}$, Tomasz CHACIŃSKI ${ }^{2}$ \\ ${ }^{1 *}$ Faculty of Mechanical Engineering, Department of Production Engineering, Koszalin University \\ of Technology, Raclawicka 15-17, 75-620 Koszalin, Poland, e-mail: bartlomiej.wietrak@gmail.com \\ ${ }^{2}$ Faculty of Mechanical Engineering, Department of Production Engineering, Koszalin University \\ of Technology, Poland, e-mail: tomasz.chacinski@tu.koszalin.pl
}

(Received 15 January 2021, Accepted 31 January 2021)

\begin{abstract}
The main goal of the work was to create a project to implement an object recognition system into a modular didactic gear production system. The project shows how, thanks to the modular structure of the gear system, it is possible to easily add new elements to it, at the same time increasing its capabilities. At the beginning, the characteristics of the system were presented before the implementation, including a description of the production process that takes place in this system and all modules of the system were exchanged. Then the vision system for object recognition and all its components were described. The technical-organizational project of the implementation presented the concept of the deployment of the system modules and the principle of system operation after the implementation. A 3D model of all system components was also presented.
\end{abstract}

Keywords: object recognition system, vision system, system implementation, modular production system, gears

\section{INTRODUCTION}

In the manufacturing industry, whether it be food or mechanical engineering, it is increasingly common to find various types of vision systems that enable noninvasive quality control, relieving the burden on employees who no longer need to perform tedious tasks. They are also used in production processes to recognize components, or in warehouse processes in the form of very simple barcode readers, which facilitate and organize the labeling of individual products or entire pallets, cargoes $[2,3,5]$.

Vision systems can also be implemented into modular didactic manufacturing systems, and this is the focus of this paper. An object recognition system has been implemented into a modular didactic gear manufacturing system. This makes it possible to simulate many new manufacturing processes in an existing system without having to build a new one. The paper presents the technical and organizational design of the implementation of the vision system, which shows the concept of arrangement of individual modules in the system after the finished implementation and the principle of their operation. This has been described in the literature by Wietrak [5].

The MDPS system now consists of the following modules, which are numbered as shown in Fig. 1 and 2 [1].

1. Component manufacturing station using the additive method for rapid prototyping of FDM.

2. The R1 robot arm is designed for the transport of components.

3. A rail for the R1 robot arm to extend its working range.

4. Quality control station for components and finished products.

5. Intermediate Product Warehouse.

6. S1 belt conveyor transporting elements from S1a to $\mathrm{S} 1 \mathrm{~b}$.

7. R2 robot arm for transport and assembly.

8. Assembly station.

9. $\mathrm{S} 2$ belt conveyor transporting elements from $\mathrm{S} 2 \mathrm{a}$ to $\mathrm{S} 2 \mathrm{~b}$.

10. Pallet depot.

11. Warehouse for finished goods with a landfill site. 


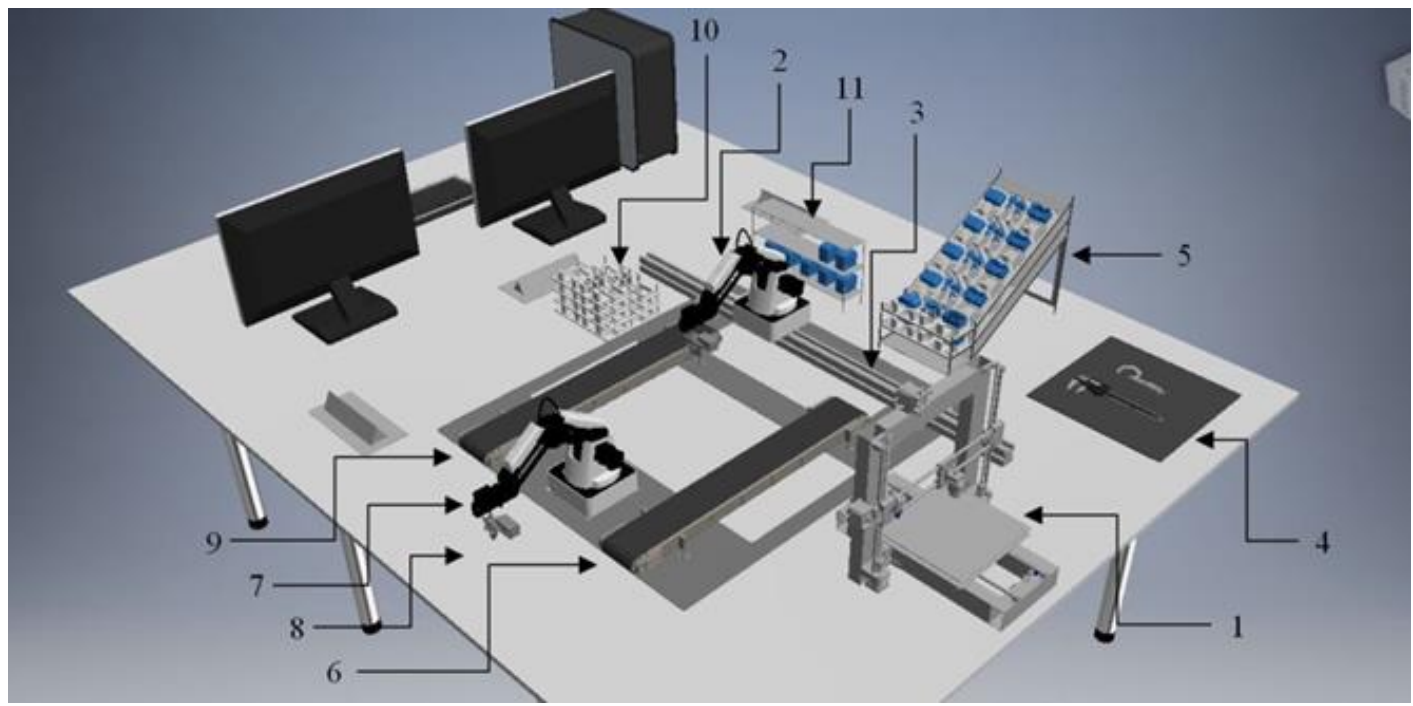

Fig. 1. Didactic, modular production system MDPS [4]

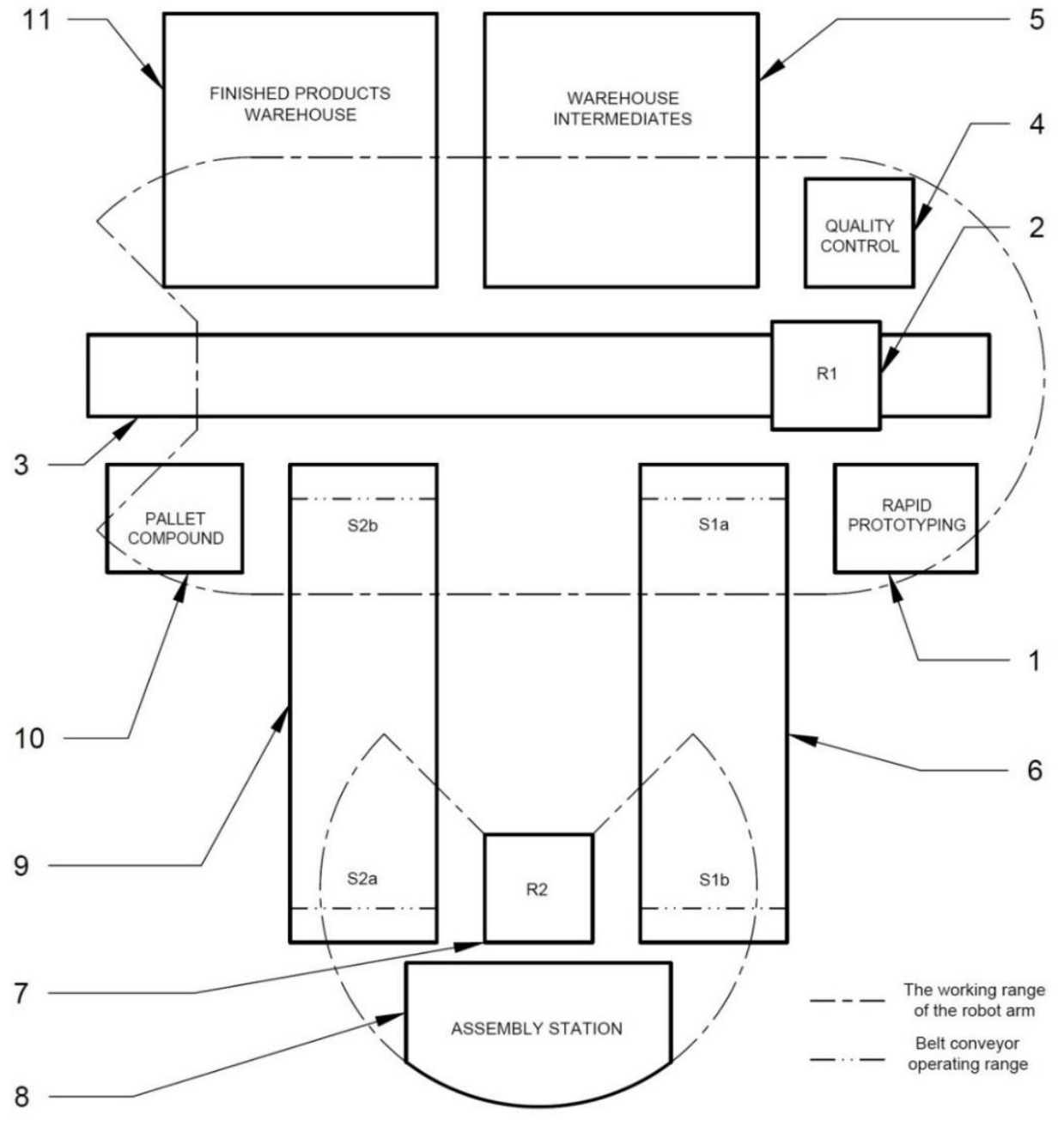

Fig. 2. Diagram of the MDPS single-stage gearing concept [1] 


\section{VISUAL OBJECT RECOGNITION SYSTEM}

The basis of the MDPS is Dobot's robot arms. These are Robot Magician models allowing for manipulation of gear elements and their transport between successive stages of the production process. The aim of the project is to implement an object recognition system into the existing gear production system. This task will be fulfilled by one of the robot arms already in the system, but it will be equipped with additional tooling dedicated by Dobot for this purpose. The set of equipment is called the Robot Vision Kit (Fig. 3). By combining the robot arm with a camera, it will be possible to significantly extend the range of processes that can be simulated in the system.

The main components included in the Dobot Magician - Robot Vision Kit [6] are:

- industrial camera,

- light source,

- industrial camera lens,

- base,

- telescope,

- black and white calibration plate,

- telescope pedestal,

- camera mount.

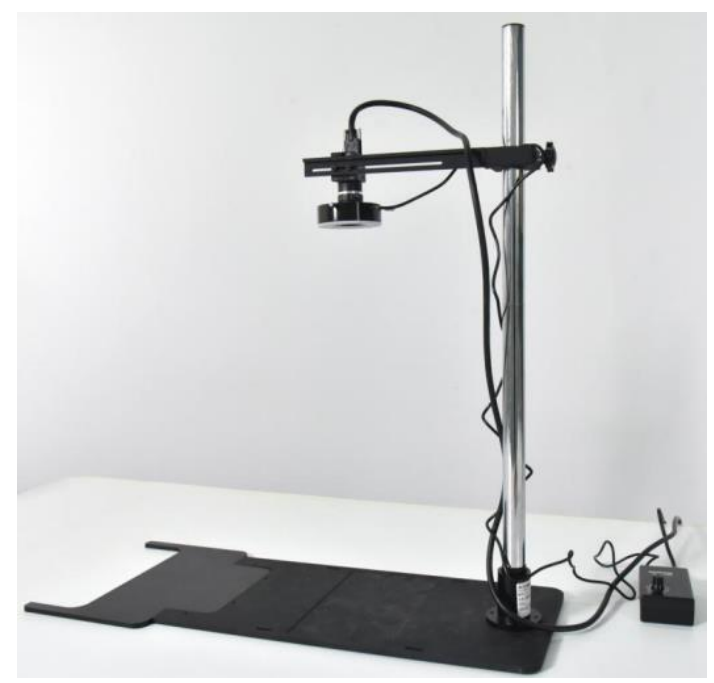

Fig. 3. Robot Vision Kit by Dobot [7]

Industrial camera armed with a lens and light source is placed in a special H-shaped holder, which allows moving the camera in two axes over the work field. The source of white light illuminates objects placed in the working field of the system, which improves the operation of the industrial camera. The fact that the light source is placed directly on the camera ensures that it illuminates exactly what the camera is pointing at any given moment.

The main working components of the Robot Vision Kit object recognition system are the industrial camera, the lens and the light source. Tables 1, 2, and 3 show their technical specifications [6].

\section{IMPLEMENTATION PROJECT OF VISUAL RECOGNITION SYSTEM INTO THE MDPS}

This chapter presents a conceptual scheme of the operation of the modular didactic production system after implementing the object recognition system into it, and a description of the production occurring in this system.

Tab. 1. Technical specifications of the industrial camera [6]

\begin{tabular}{ll}
\hline Sensor size & 1 ' $^{\prime}$ CMOS \\
\hline Sensor type & MT9T001 \\
\hline Effective pixels & 3 million \\
\hline Pixel size & $3.2 \times 3.2 \mu \mathrm{m}$ \\
\hline
\end{tabular}

Frame rate /

Resolution

$12 / 2048 \times 1536$

\begin{tabular}{ll}
\hline Exposure time & $50.8 \mu \mathrm{s}-3329 \mathrm{~ms}$ \\
\hline Size & $45 \times 45 \times 40 \mathrm{~mm}$ \\
\hline Data interface & USB 2.0 \\
\hline $\begin{array}{l}\text { Operating } \\
\text { temperature }\end{array}$ & $0^{\circ} \mathrm{C}$ to $70^{\circ} \mathrm{C}$ \\
\hline
\end{tabular}

Tab. 2. Technical specifications of the lens [6]

Focus $16 \mathrm{~mm}$

Working range

aperture

F1.4-F16C

$\begin{aligned} & \text { Operating } \\ & \text { temperature }\end{aligned}-20^{\circ} \mathrm{C}$ to $50^{\circ} \mathrm{C}$

\begin{tabular}{ll}
\hline Lens mount & C mount \\
\hline Filter size & M30.5P $+0.5 \mathrm{~mm}$ \\
\hline Size & $33.5 \mathrm{~mm} \times 28.2 \mathrm{~mm}$ \\
\hline Weight & $65 \mathrm{~g}$ \\
\hline $\begin{array}{l}\text { Optical } \\
\text { magnification }\end{array}$ & \begin{tabular}{l}
$0.05 \times-0.06 \times-0.08 \times-0.10 \times-$ \\
\hline
\end{tabular}
\end{tabular}

Expangind ring $\quad 0-0.5-1.0-1.5$ 
Tab. 3. Technical specifications of the light source [6]

Number of LEDs 48

\begin{tabular}{ll}
\hline Illumination & 40000 lux \\
\hline Beam lenght & $455 \mathrm{~nm}$ to $457.5 \mathrm{~nm}$ \\
\hline Output & $12 \mathrm{~V} / 3.5 \mathrm{~W}$ to $5 \mathrm{~W}$ \\
\hline
\end{tabular}

Working distance $35 \mathrm{~mm}$ to $11 \mathrm{~mm}$

\begin{tabular}{ll}
\hline & $\begin{array}{l}\text { Inner diameter: } 40 \mathrm{~mm} \\
\text { Outer diameter: } 70 \mathrm{~mm}\end{array}$ \\
& $\begin{array}{l}\text { Height: } 25 \mathrm{~mm} \\
\text { Outer diameter of lamp: } \varnothing 39 \mathrm{~mm}\end{array}$ \\
\hline Weight & $0.48 \mathrm{~kg}$ \\
\hline
\end{tabular}

Operating temperature

\subsection{Description of modular didactic production system after implementation of object recognition system}

Once the object recognition system is implemented into the MDPS, it consists of the following modules, whose designations correspond to those in Figure 4.

1. FDM rapid prototyping workstation.

2. The $\mathrm{R} 1$ robotic arm

3. Robot arm R2.

4. Robot arm R3.

5. Conveyor belt $\mathrm{S} 1$.

6. Conveyor belt $\mathrm{S} 2$.

7. Robot Working Range Extending Rail R1.

8. Warehouse for semi-finished products 1 .

9. Warehouse for semi-finished products 2 .

10. Object recognition system.

11. Assembly station.

12. Quality control station.

13. Pallet storage.

14. Warehouse for finished products.

Figure 4 shows a schematic of the concept of operation of the modular didactic production system after implementing the object recognition system into it.

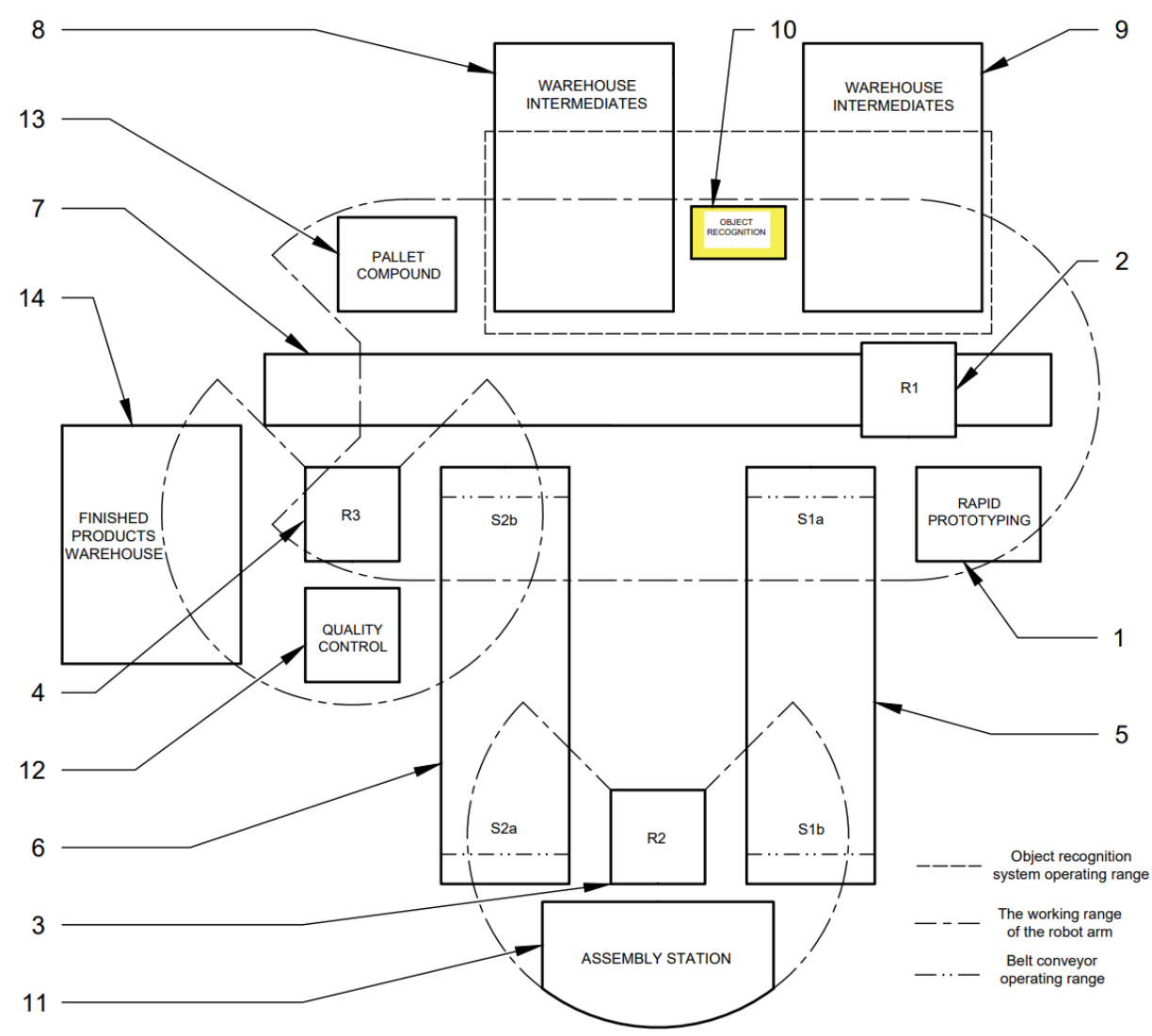

Fig. 4. Schematic of MDPS system after implementation of object recognition system [4] 


\subsection{Description of the production process after implementation of the object recognition system}

The initial manufacturing steps in the described system after the implementation of the object recognition system are the same as before the implementation. First, the components are manufactured using the additive FDM prototyping method. They then undergo a quality check and, if positive, are palletized and stored in one of two semifinished product warehouses that are located on either side of the object recognition system in such a way that they are simultaneously in the camera frame of the vision system.

Then the robotic arm R1, thanks to the information received from the vision system, picks up the corresponding pallet with the component and transports it to point S1a. Conveyor belt S1 transports the pallet to $\mathrm{S} 1 \mathrm{~b}$, where robot arm R2 picks the component from the pallet and transfers it to the assembly station. Once this is done, robot arm R2 moves the empty pallet to point $\mathrm{S} 2 \mathrm{a}$, from where conveyor belt $\mathrm{S} 2$ transports it to point $\mathrm{S} 2 \mathrm{~b}$. Robot arm R3 picks the empty pallet from $\mathrm{S} 2 \mathrm{~b}$ and transfers it to the storage bay. Then, the abovedescribed steps from picking the pallet with the component to the empty pallet storage step are repeated for the remaining gear components.

After the assembly operation is completed, the robotic arm R2 moves the finished gearbox to the point $\mathrm{S} 2 \mathrm{a}$, from where it is transported via the conveyor belt $\mathrm{S} 2$ to the point $\mathrm{S} 2 \mathrm{~b}$. Then the robot arm R3 moves the finished gearbox to the quality control station, where the correctness of its manufacture is checked. If the gearbox was made correctly, the R3 robot arm will move it to the finished goods warehouse. If a defect is detected during quality inspection, a manual attempt is made to eliminate the defect. If the possible defect cannot be corrected, the gearbox will be moved to the stockyard.

Figures 5 and 6 present MDPS system after implementation od the object recognition system.

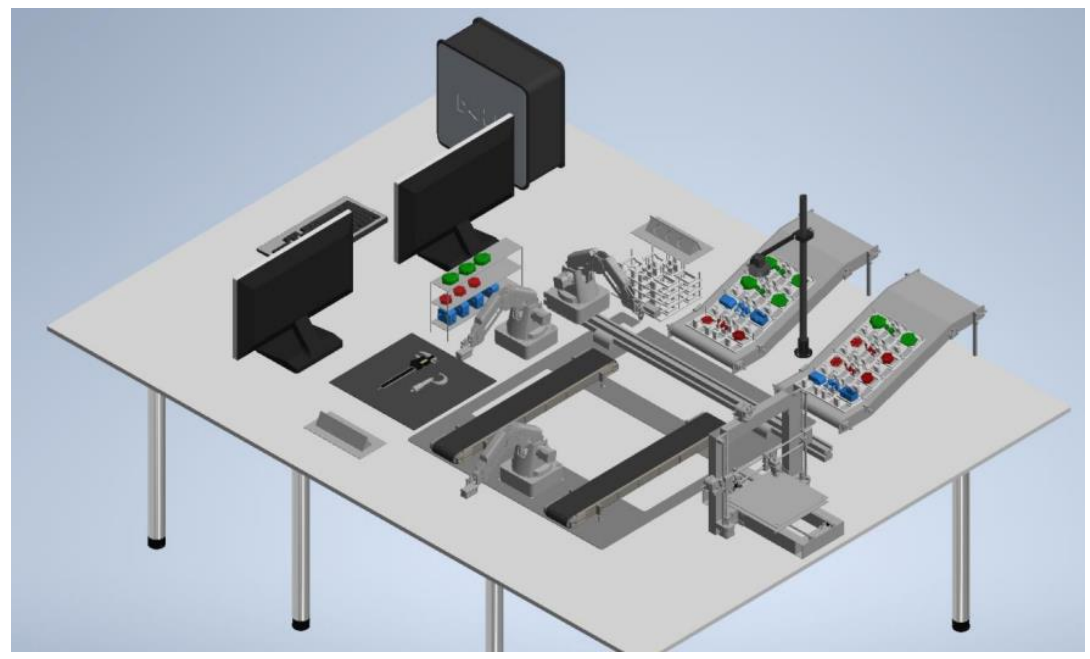

Fig. 5. MDPS system after implementation [4]

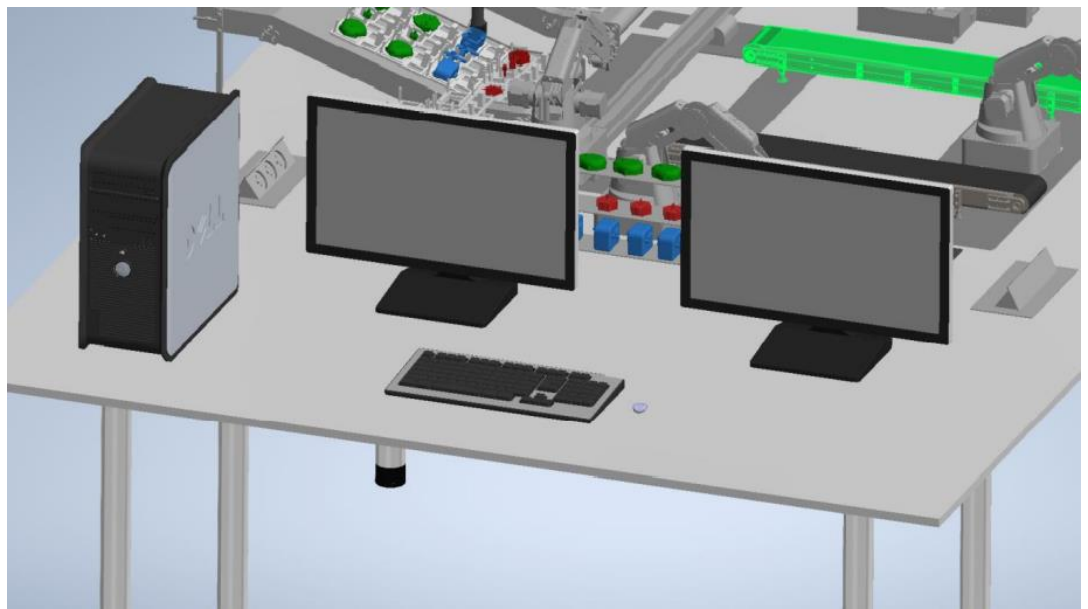

Fig. 6. MDPS System Control Center [4] 


\section{SUMMARY AND CONCLUSIONS}

The presented work presents a technical and organizational project for the implementation of an object recognition system into a modular didactic gear production system, which, thanks to this implementation, has the possibility to produce not only single-stage gears, but also two-stage and planetary gears.

During the implementation, the characteristics of the vision-based object recognition system were developed and the existing gear manufacturing system, its components and subsequent stages of gear manufacturing were described. A technical project and an organizational project for the implementation of the object recognition system were created, in which the production process after the implementation was described. Moreover, newly implemented modules and those that have been modified during the implementation have been described. Finally, a 3D model of the MDPS system after implementation of the vision system has been developed.

The following conclusions were drawn from the presented study.

1. The implementation of the object recognition system into the MDPS system further extends the possibilities of various simulations of manufacturing processes in this system. It also makes the system can be called flexible.

2. The implementation of an additional object recognition system in the production system, forced the need to modify the existing warehouse for semi-finished products, as well as to change the location of some other modules such as: pallet storage and quality control station.

3. The vision system that was implemented into the MDPS system is also manufactured by Dobot, which greatly facilitated its implementation into the system.

4. When working with vision systems, special attention must be paid to the placement of the camera in the system. This should be done in such a way as to get the largest possible area contained within the camera frame. In the present case, it was necessary to modify the semi-processing warehouse. It was divided into two separate intermediate product storages that were placed on either side of the vision system.

5. By creating a diagram of the relationship between subsystems by process mapping, both before and after the implementation of the vision system in the system, it is easy to analyze the course of the production process in both cases.

\section{Nomenclature}

Acronyms
MDPS - modular didactic production system
FDM - fused deposition modeling

\section{References}

1. Jaskólski P., 2018, Projekt techniczno-organizacyjny modułowego dydaktycznego systemu produkcji przekładni zębatych, engineering thesis supervised by prof. K. Nadolny, Politechnika Koszalińska.

2. Jaskólski P., Nadolny K. 2018, Characteristics of didactic modular production systems, Journal of Mechanical and Energy Engineering 4, pp. 263-268.

3. Jaskólski P., Nadolny K., 2019, Characteristics of functional subsystems of modular didactic production system for gear trains, Journal of Mechanical and Energy Engineering 4, pp. 301-308.

4. Jaskólski P., Nadolny K., 2019, Characteristic of process flow in modular didactic production system for gear trains, Journal of Mechanical and Energy Engineering 2, pp. $115-120$.

5. Wietrak B., 2020, Projekt wdrożenia układu rozpoznawania przedmiotów do modułowego dydaktycznego systemu produkcji przekładni zębatych, engineering thesis supervised by prof. K. Nadolny Politechnika Koszalińska.

6. https://www.dobot.cc (accessed: May 2020).

7. https://www.robotshop.com/eu/en/dobot-magician-robotvision-kit-open-box.html (accessed: May 2020).

8. https://botland.com.pl/dobot-ramie-robota/13698-dobotmagician-robot-vision-kit.html (accessed: May 2020).

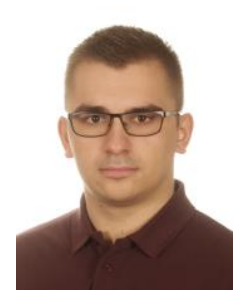

\section{Biographical notes}

Bartlomiej Wietrak defended his diploma thesis in 2020 at the Faculty of Mechanical Engineering of the Koszalin University of Technology, in Management and Production Engineering, specializing in Manufacturing Process Logistics. Currently he is an employee of the KabelTechnik Poland as a junior SQA specialist.

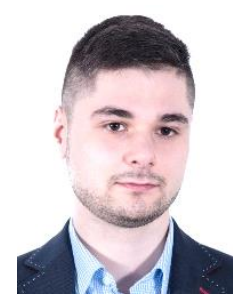

Tomasz Chaciński is currently preparing to defend his Bachelor of Engineering thesis. He is an employee of the Faculty of Production Engineering at the Department of Mechanical Engineering, Technical University of Koszalin. His interests include solving problems in production processes organization, improvement of production systems through automation of their processes and application of dynamic quality control methods. 